Ann. Biol. anim. Bioch. Biophys., I975, 15 (2), 383-384.

\title{
ESTRUS CONTROL \\ IN GILTS WITH NORETHANDROLONE INJECTIONS AND AN ANALOGUE OF PROSTAGLANDINS (ICI 80996)
}

\author{
Françoise MARTINAT-BOTTE \\ Station de Physiologie de la Reproduction, \\ Centre de Recherches de Tours, I. N.R. A., \\ Nouzilly, 37380 Monnaie \\ I. T. P., 149 rue de Bercy, \\ i501: Paris
}

The norethandrolone (I $7 \alpha$-ethylnortestosterone) controls efficiently the sexual cycle in gilts. A treatment of nine or eighteen injections (IM) (30 mg norethandrolone per injection each day) was begun at the different days of the estrous cycle $\left(D_{1}\right.$ to $\left.D_{19}\right)$. A coelioscopic examination of the ovaries at nine or eighteen days after the first injection informs about the presence of corpus luteum or cystic follicles. Whatever the length of the treatment, no kystic follicle was observed during or after the progestagen administration.

An effective oestrus synchronization exists after a long term treatment $(20 / 2 \mathrm{I}$ gilts in oestrus 5 days after the last injection). But with a short term period of injections, begun between $\mathrm{D}_{1}-\mathrm{D}_{5}$, oestrus are grouped between the 6 th-8th days posttreatment in only $\mathrm{I} / 3$ of gilts $(7 / 2 \mathrm{I})$. The original corpus luteum remains functionnal at the end of progestagen treatment $\left(\mathrm{D}_{9}\right.$ to $\left.\mathrm{D}_{13}\right)$. Two injections of $500 \mu \mathrm{g}$ of $\mathrm{ICI}$ 80996 have a luteolytic effect on this $\mathrm{D}_{10}$ to $\mathrm{D}_{14}$ corpus luteum (GUThriE \& PoLGE, I973). A good synchronization was observed (I4/I5 gilts in oestrus between $D_{6}-D_{8}$ after the last progestagen injection). With a short term treatment begun between $D_{6}$ to $D_{19}$ of the oestrus cycle, oestrus synchronization is effective with or without prostaglandin injections ( $48 / 6 \mathrm{I}$ in oestrus during the same reference period). Fertility expressed in controlled presence of embryos at the 3oth of pregnancy related to the treated animals was respectively : 9 days norethandrolone + ICI $80996: 78$ p. Ioo (I8/23) ; 9 days norethandrolone alone : 63.6 p. Ioo (I6/26) ; for the second treatment, the period $D_{1}-D_{5}$ of the oestrus cycle resulting in unsynchronised oestrus is not considered. With prostaglandin, the result is obtained whatever the first day of the treatment. 


\title{
ACKNOWLEDGMENT
}

We are indebted to Imperial Chemical Industries Ldt for the gencrous gift of the prostaglandin analogues and to Searle France, Veterinary Department, for the generous supply of norethandrolone.

\author{
RÉSUMÉ \\ CONTRLỐE DE I'ESTRUS CHEZ LA TRUIE NULLIPARE \\ PAR INJECTIONS DE NORETHANDROLONE \\ ET D'UN ANALOGUE DES PROSTAGLANDINES (ICI 80996)
}

Chez la Truic, l'injection journalière de $30 \mathrm{mg}$ de norethandrolone pendant $\mathrm{I} 8$ jours permet de grouper les oostrus 5 jours après l'arrêt du traitement.

Un traitement de 9 jours permet le groupage des oestrus, à condition que les injections commencent apres le $5^{c}$ jour du cycle. On obtient la synchronisation des chaleurs et une fertilité de $7^{8}$ p. roo en associant 9 jours de norethandrolone et deux injections de $500 \mu \mathrm{d}^{\prime} u n$ analogue des prostaglandines.

\section{REFERENCE}

Guturie, Polgi, r973. Effect of an analogue of prostaglandin I'ex (ICI 79939) on luteal function of the pig during the oestrus cycle. Soc. Study Fort., London (Abstr.), 25. 